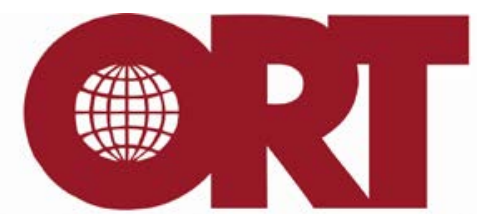

UNIVERSIDAD ORT

Uruguay

\title{
Intra-generational social mobility and entrepreneurship in Uruguay
}

\author{
Bukstein, Daniel \\ Universidad ORT Uruguay \\ Gandelman, Néstor \\ Universidad ORT Uruguay \\ $*$
}

Agosto de 2012

\begin{abstract}
This paper follows an income-based, time-dependence approach to measure social mobility in Uruguay between 1982 and 2010. The paper finds that social mobility in Uruguay is considerable and reports evidence suggesting that this mobility is greater within cohorts of groups, such as those defined by gender or region, than between groups. Entrepreneurship and self-employment are associated with greater social mobility.
\end{abstract}

JEL codes: O15, L26, D31

Keywords: income mobility, social mobility, entrepreneurship, pseudo-panels

Documento de Investigación, Nro. 78, agosto 2012. Universidad ORT Uruguay.

Facultad de Administración y Ciencias Sociales. ISSN 1688-6275

\footnotetext{
* The authors thank Virginia Robano, Eduardo Lora, Francesca Castellani, and participants at the IDB organized discussion workshop "Strengthening Mobility and Entrepreneurship: A Case for the Middle Classes" for helpful comments and suggestions. All errors and omissions are the authors'. Daniel Bukstein (danielbukstein@hotmail.com) is a graduate student at Universidad ORT Uruguay. Nestor Gandelman (gandelman@ort.edu.uy) is the Director of the Department of Economics of Universidad ORT Uruguay.
} 


\section{Introduction}

Among Latin American countries, Uruguay has the lowest income inequality. However, inequality and segregation have been growing in Uruguay, accompanied by greater polarization between the rich and the poor.

The relatively large size of the Uruguayan government has often been considered responsible for the better income inequality statistics that the country has when compared to other Latin American countries. Moreover, Uruguayans tend to view themselves as a risk-averse people that prefer the safety of a stable public sector job over other riskier alternatives. There is recent anecdotal evidence of this. Although in 2011 the labor market showed the lowest unemployment rates since official statistics have been available, several public announcements of vacancies in public institutions garnered a huge response from interested individuals.

The Organisation for Economic Co-operation and Development (OECD) (2011) presented evidence that the government and the middle sectors are more connected in Uruguay than in other countries. Of employed middle sector household members, 21 percent work in public administration. This is the highest figure for a Latin American country. Assuming that this is the case, we asked whether there is a link between entrepreneurship and social mobility.

In this paper we explore the relationship between entrepreneurship and intragenerational social mobility. One problem that must be addressed is attrition. Suppose that panel data shows that at age 18 all individuals must decide whether to apply for a salaried job or start a new enterprise. As time passes, many who chose to become entrepreneurs will fail and end up joining the labor force. Without controlling for this survival bias, we would overestimate the impact of entrepreneurship in social mobility.

In this paper, we use repeated cross-sectional (RCS) surveys to construct pseudopanels. Although RCS data have disadvantages compared to real panel data, they are superior in two dimensions. First, in a cohort of entrepreneurs, there are some who are successful and some who fail. The data from the cohort represent an average of all these individuals and, therefore, the problem of non-random sample attrition is minimized. Second, pseudo-panels have fewer measurement problems because they average individuals in adequately constructed cohorts. With large enough cohorts the average 
measurement error tends to be zero. Our data come from household surveys from 1982 to 2010.

The goals of this paper are:

a. to evaluate social mobility convergence in Uruguay, and

b. to evaluate differences in social mobility according to gender, place of residence, education level, and differences in social mobility due to entrepreneurship or self-employment.

\section{Data}

We use household surveys (Encuesta Continua de Hogares-ECH) from the National Institute of Statistics (Instituto Nacional de Estadística-INE). These surveys are taken annually and they gather data on household composition, including age, gender, educational level, and labor market variables. The ECH surveys cover Montevideo, the capital city, and urban areas in the rest of the country with over 5,000 inhabitants. It has only been since 2006 that the INE has started to gather information for rural settings. Therefore, our study is restricted to urban areas. We include heads of household 21-65 years old. Table 1 reports the number of households considered in this paper. 


\begin{tabular}{|c|c|c|c|c|c|c|}
\hline & Capital city & $\begin{array}{l}\text { Unweighted } \\
\text { Rest of the } \\
\text { country }\end{array}$ & Total & Capital city & $\begin{array}{l}\text { Weighted } \\
\text { Rest of the } \\
\text { country }\end{array}$ & Total \\
\hline 1982 & 9,184 & & 9,184 & 431,648 & & 431,648 \\
\hline 1983 & 9,317 & & 9,317 & 437,899 & & 437,899 \\
\hline 1984 & 9,158 & 11,030 & 20,188 & 430,426 & 584,590 & $1,015,016$ \\
\hline 1985 & 9,128 & & 9,128 & 429,016 & & 429,016 \\
\hline 1986 & 9,097 & 10,397 & 19,494 & 427,559 & 551,041 & 978,600 \\
\hline 1987 & 9,170 & 10,818 & 19,988 & 430,990 & 573,354 & $1,004,344$ \\
\hline 1988 & 9,248 & 11,064 & 20,312 & 434,656 & 586,392 & $1,021,048$ \\
\hline 1989 & 9,501 & 9,118 & 18,619 & 446,547 & 483,254 & 929,801 \\
\hline 1990 & 9,432 & 9,097 & 18,529 & 443,304 & 482,141 & 925,445 \\
\hline 1991 & 9,451 & 8,826 & 18,277 & 444,197 & 467,778 & 911,975 \\
\hline 1992 & 9,477 & 9,081 & 18,558 & 445,419 & 481,293 & 926,712 \\
\hline 1993 & 9,728 & 8,940 & 18,668 & 457,216 & 473,820 & 931,036 \\
\hline 1994 & 9,700 & 9,056 & 18,756 & 455,900 & 479,968 & 935,868 \\
\hline 1995 & 9,637 & 9,723 & 19,360 & 452,939 & 515,319 & 968,258 \\
\hline 1996 & 9,843 & 9,692 & 19,535 & 462,621 & 513,676 & 976,297 \\
\hline 1997 & 9,680 & 9,711 & 19,391 & 454,960 & 514,683 & 969,643 \\
\hline 1998 & 8,578 & 8,650 & 17,228 & 406,122 & 361,945 & 768,067 \\
\hline 1999 & 10,048 & 7,881 & 17,929 & 394,414 & 371,480 & 765,894 \\
\hline 2000 & 10,203 & 7,926 & 18,129 & 401,007 & 372,393 & 773,400 \\
\hline 2001 & 10,345 & 8,132 & 18,477 & 403,596 & 372,561 & 776,157 \\
\hline 2002 & 10,268 & 8,145 & 18,413 & 400,320 & 374,919 & 775,239 \\
\hline 2003 & 10,215 & 8,117 & 18,332 & 398,450 & 373,638 & 772,088 \\
\hline 2004 & 10,330 & 8,057 & 18,387 & 402,210 & 370,707 & 772,917 \\
\hline 2005 & 10,356 & 8,146 & 18,502 & 404,036 & 374,440 & 778,476 \\
\hline 2006 & 29,736 & 28,775 & 58,511 & 439,418 & 457,080 & 896,498 \\
\hline 2007 & 20,670 & 21,865 & 42,535 & 437,941 & 459,108 & 897,049 \\
\hline 2008 & 19,453 & 20,460 & 39,913 & 432,397 & 407,466 & 839,863 \\
\hline 2009 & 20,301 & 20,439 & 40,740 & 450,182 & 466,029 & 916,211 \\
\hline 2010 & 18,294 & 24,895 & 43,189 & 448,372 & 586,385 & $1,034,757$ \\
\hline
\end{tabular}

Source: Authors' calculations based on household surveys. 


\section{Methodology}

\subsection{Measuring Social Mobility with Pseudo-panels}

For the income-based time-dependence approach to social mobility, we begin with the following regression:

$$
y_{i t}=\beta y_{i t-1}+u_{i t}
$$

where $y_{i t}$ represents the log of per capita income of household $i$ at time $t$ and $u_{i t}$ is a disturbance term. The coefficient $\beta$ of the lagged income is the measure of social mobility. A value of $\beta$ equal to (1) is interpreted as a situation of no social mobility, whereas a value of $\beta$ below the unity represents a situation of income convergence. A situation of total income mobility occurs in the extreme case of $\beta$ equal to 0 when current income has no relationship to its past value. The coefficient $\beta$ obtained from (1) is usually referred to as a measure of unconditional convergence, as it is estimated in a regression with no further covariates than past income.

Including additional controls in the regression leads to an estimate of $\beta$ which constitutes the conditional convergence:

$$
y_{i t}=\beta y_{i t-1}+\not X_{i t}+u_{i t}
$$

where $X$ is a vector of covariates and $\gamma$ measures the impact of these covariates on present income.

To conduct this kind of analysis, the researcher ideally should have information about the same individuals over time, which means that the best type of data that could be used is panel data. Panel data are not, however, available in developing regions such as Latin America. Deaton (1985) presented a way to address the paucity of panel data by constructing pseudo-panels using a series of repeated cross-sections. A pseudo-panel is formed by creating synthetic observations obtained by averaging observations from groups of individuals, usually called cohorts, with similar time-invariant characteristics in a sequence of repeated cross-sectional data sets. The most commonly used of these characteristics is birth year, although it may also be combined with gender, place of residence and/or educational level, or other characteristics of the household. This way, the cohorts can be viewed as being "followed" over time, the same way individuals are followed over time with true panel data; hence the name pseudo- panel. 
Considering the pseudo-panel nature of the data, equations (1) and (2) take the following form:

$$
\begin{aligned}
& \bar{y}_{c(t), t}=\beta \bar{y}_{c(t), t-1}+u_{c(t), t} \\
& \bar{y}_{c(t), t}=\beta \bar{y}_{c(t), t-1}+\delta \bar{X}_{c(t), t}+u_{c(t), t}
\end{aligned}
$$

where the individual index $i$ has been replaced by the cohort index $c(t)$. The notation $c(t)$ indicates that the cohort is time-dependent, while the flat lines above the variables indicate that the values represent sample averages of the cohort $c(t)$ in period $t$. Like equations (1) and (2), the coefficient $\beta$ of lagged income is interpreted as a measure of unconditional or conditional convergence. There is a great deal of literature that addresses the conditions under which the parameters of equation (3) and (4) can be consistently estimated, given the limitations that arise when working with pseudo-panel data as opposed to real panel data. Some of this literature can be found in Deaton (1985), Moffitt (1993), Verbeek and Vella (2002) and Antman and McKenzie (2005), among others.

\subsection{Measuring Social Mobility for Groups of Interest}

In this section we extend the income-based approach to measure social mobility for specific sectors. We illustrate this by considering gender differences, but the same approach can address differences in regions of the country, in terms of head of household, education, or entrepreneurship.

Examining the simpler case, suppose we have panel data and we can follow the same set of households over time. One way to measure females' social mobility is to estimate a regression of the form:

$$
y_{i t}=\beta_{1} y_{i t-1}+\beta_{2} y_{i t-1} f_{i}+f_{i}+u_{i t}
$$

where $f_{i}$ is a dummy variable valued at 1 if the ith household head is female and 0 otherwise. In this case, the slope coefficient $\beta_{1}$ represents income mobility for males, while the sum $\beta_{1}+\beta_{2}$ represents social mobility for females.

To estimate the cohort version of (5), we have to adequately define the cohorts. If, for example, cohorts are defined by birth year and gender, the cohort version of equation (5) is:

$$
\bar{y}_{c(t) t}=\beta_{1} \bar{y}_{c(t), t-1}+\beta_{2} \bar{y}_{c(t), t-1} f_{c(t)}+f_{c(t)}+u_{c(t) t}
$$


where $f_{c(t)}$ is a dummy variable indicating a cohort of females. The interpretation of equation (6) is similar, $\beta_{1}+\beta_{2}$ is the income mobility for females, while $\beta_{1}$ is the income mobility for males. Using this procedure, we can consider all groups of interest.

\subsubsection{Pseudo-panel Construction}

In constructing the cohorts, we made sure they were large enough. Otherwise the average characteristics per cohort would not result in good estimates for the population cohort means. If the cohort size is too large, then the cohorts that comprise the number of observations in our estimations will be small. The dilemma between cohort size versus number of cohorts becomes essential for the consistent estimation of pseudo-panels. In this vein, Verbeek and Nijman (1992) and Antman and McKenzie (2005) show that large cohort sizes are necessary to ignore the "artificial" nature of pseudo-panel data, and to treat them as genuine panels that allow for consistent estimates of the parameters.

The cohorts were constructed using household heads between the ages of 21 and 65 , born in five-year spans. In our estimations we have expanded this definition. We also define pseudo-panels by birth year and gender, by birth year and region (i.e., capital city versus the rest of the country), by birth year and education level (above and below the birth cohort median), by birth year and entrepreneurship status, and by birth year and self-employment status. In all cases, frequency weights were used to appropriately mimic the structure of the Uruguayan population.

Given that we are working with household heads between ages 21 and 65 and that our first survey year is 1982, the first cohort observed contained individuals born between 1920 and 1924, and the last cohort contained individuals born between 1980 and 1984 in 2010. Note that the aggregation of individuals born in five different years causes each of the survey year cohorts to be measured over a span of ages, e.g., the 1920-1924 birth cohort in 1982 is observed from 58 to 62 . As we were not able to follow all the individuals, or cohorts, over time in an equal number of periods because of restrictions imposed by the available survey years and the ages we worked with, we ended up with an unbalanced pseudo-panel of 13 cohorts and 237 observations. When the cohort is defined by birth year and other characteristics, such as gender, region, education, and entrepreneurship/self-employment, we end up with twice as many cohorts and 
observations. Table 2 shows the distribution of the 237 observations in the birth year cohort definition, the average number of household heads in each cohort, and the percentage of entrepreneurs, females, and residents in the capital city. The cohort defined by birth year and education takes the median cohort education level and divides it between those more and less educated. The median cohort education level was calculated for each cohort for the whole time that it was observed. 


\begin{tabular}{|c|c|c|c|c|c|c|c|c|c|c|c|c|}
\hline \multicolumn{13}{|c|}{ Table 2. Cohorts } \\
\hline Cohort & $\begin{array}{c}\text { First } \\
\text { survey } \\
\text { year }\end{array}$ & $\begin{array}{l}\text { Last } \\
\text { survey } \\
\text { year }\end{array}$ & $\begin{array}{l}\text { First } \\
\text { age } \\
\text { span }\end{array}$ & $\begin{array}{l}\text { Last } \\
\text { age } \\
\text { span }\end{array}$ & $\begin{array}{l}\text { Observ } \\
\text { ations }\end{array}$ & $\begin{array}{c}\text { Average } \\
\text { amount of } \\
\text { individuals } \\
\text { (unweighted) }\end{array}$ & $\begin{array}{l}\text { Average } \\
\text { amount of } \\
\text { individuals } \\
\text { (weighted) }\end{array}$ & $\begin{array}{c}\% \text { of } \\
\text { entrepre } \\
\text { neurs }\end{array}$ & $\begin{array}{c}\% \text { of self } \\
\text { employed } \\
\text { without } \\
\text { fixed } \\
\text { workplace }\end{array}$ & $\begin{array}{c}\% \text { of self } \\
\text { employed } \\
\text { without } \\
\text { fixed } \\
\text { workplace }\end{array}$ & $\begin{array}{c}\% \text { of } \\
\text { females }\end{array}$ & $\begin{array}{l}\% \text { in } \\
\text { the } \\
\text { capital } \\
\text { city }\end{array}$ \\
\hline $1980-$ & & & & & & & & & & & & \\
\hline 1984 & 2005 & 2010 & $21-25$ & $26-30$ & 6 & 1225 & 59198 & $4.05 \%$ & $5.14 \%$ & $2.26 \%$ & $27.48 \%$ & $75.96 \%$ \\
\hline 1975- & & & & & & & & & & & & \\
\hline $\begin{array}{c}1979 \\
1970-\end{array}$ & 2000 & 2010 & $21-25$ & $31-35$ & 11 & 1688 & 83345 & $4.89 \%$ & $5.72 \%$ & $2.99 \%$ & $25.32 \%$ & $57.68 \%$ \\
\hline $\begin{array}{c}1974 \\
1965-\end{array}$ & 1995 & 2010 & $21-25$ & $36-40$ & 16 & 1817 & 90191 & $6.27 \%$ & $6.50 \%$ & $3.07 \%$ & $25.12 \%$ & $53.07 \%$ \\
\hline $\begin{array}{l}1969 \\
1960-\end{array}$ & 1990 & 2010 & $21-25$ & $41-45$ & 21 & 1637 & 79858 & $6,72 \%$ & $7.32 \%$ & $3.23 \%$ & $23.88 \%$ & $51.16 \%$ \\
\hline $\begin{array}{c}1964 \\
1955-\end{array}$ & 1985 & 2010 & $21-25$ & $46-50$ & 26 & 1639 & 77721 & $6.64 \%$ & $7.66 \%$ & $3.56 \%$ & $22.92 \%$ & $50.23 \%$ \\
\hline $\begin{array}{c}1959 \\
1950-\end{array}$ & 1982 & 2010 & $23-27$ & $51-55$ & 29 & 2033 & 78618 & $6.62 \%$ & $8.48 \%$ & $3.48 \%$ & $23.12 \%$ & $48.34 \%$ \\
\hline $\begin{array}{c}1954 \\
1945-\end{array}$ & 1982 & 2010 & $28-32$ & $56-60$ & 29 & 2039 & 77252 & $6.24 \%$ & $8.46 \%$ & $3.49 \%$ & $21.08 \%$ & $48.96 \%$ \\
\hline $\begin{array}{l}1949 \\
1940-\end{array}$ & 1982 & 2010 & $33-37$ & $61-65$ & 29 & 2087 & 77213 & $5.58 \%$ & $7.53 \%$ & $3.29 \%$ & $19.49 \%$ & $50.61 \%$ \\
\hline $\begin{array}{c}1944 \\
1935-\end{array}$ & 1982 & 2005 & $38-42$ & $61-65$ & 24 & 1981 & 69474 & $5.13 \%$ & $7.21 \%$ & $3.30 \%$ & $19.86 \%$ & $49.29 \%$ \\
\hline $\begin{array}{c}1939 \\
1930-\end{array}$ & 1982 & 2000 & $43-47$ & $61-65$ & 19 & 1766 & 56070 & $5.07 \%$ & $7.47 \%$ & $3.34 \%$ & $21.27 \%$ & $48.98 \%$ \\
\hline $\begin{array}{c}1934 \\
1925-\end{array}$ & 1982 & 1995 & $48-52$ & $61-65$ & 14 & 1830 & 52025 & $3.83 \%$ & $6.94 \%$ & $3.26 \%$ & $24.14 \%$ & $50.27 \%$ \\
\hline $\begin{array}{c}1929 \\
1920-\end{array}$ & 1982 & 1990 & $53-57$ & $61-65$ & 9 & 1945 & 49123 & $3.02 \%$ & $5.42 \%$ & $3.01 \%$ & $28.24 \%$ & $51.83 \%$ \\
\hline 1924 & 1982 & 1985 & $58-62$ & $61-65$ & 4 & 1791 & 38772 & $1.89 \%$ & $4.89 \%$ & $1.94 \%$ & $34.88 \%$ & $52.60 \%$ \\
\hline Total & & & & & 237 & & & & & & & \\
\hline
\end{tabular}

Source: Authors' calculations based on household surveys.

\section{Measuring Income and Entrepreneurship}

We explore two types of social mobility according to measures of income. First, we study "absolute mobility" and measure income in per capita terms adjusted by purchasing power parity (PPP) to 2005 US dollars. ${ }^{1}$ A potential problem with this measure is that in growing economies current income should be higher than past income. Therefore, the estimation of unconditional "social mobility" using this income is an upward-biased measure of convergence.

To alleviate this problem, we consider a second alternative where income is normalized by the yearly median. This creates our measure of "relative mobility". This

\footnotetext{
${ }^{1}$ The purchasing power parity (PPP) conversion factor is the local currency unit per dollar. Source: World Development Indicators.
} 
second measure also has potential problems. When the cohorts are defined by birth year and other characteristics such as gender, there will be more than one possible normalization. The simplest alternative is to normalize yearly all individuals by the median income of that year. Another alternative is to normalize yearly all individuals of a certain group, e.g., females and males, by the median income of the group in that year. By normalizing individuals by their peers' yearly incomes, we will address social mobility among those peers, i.e., mobility of the cohorts defined within the group. Differences in the results and their interpretations are not trivial, as shown in the result section.

It is important to clarify what we mean by "entrepreneur" in this paper. Acs (2006) differentiates between opportunity and necessity entrepreneurs. The former are those who find unexploited business opportunities and transform them with their incomegenerating activity. The latter are individuals with low probabilities of successfully inserting themselves in the formal labor market who end up self-employed in lowproductivity activities. We are mostly interested in effects for opportunity entrepreneurs and not necessity entrepreneurs. Using household surveys, this distinction is difficult to make empirically because it is not easy to find good proxy variables to make this classification that are uncorrelated with income and income mobility.

Our estimations are at the household level. The household surveys allow classifying individuals by their labor status, i.e., between the status of those who own a business and have employees; those that are self-employed, have no employees and have a fixed workplace; and those that are self-employed without a fixed workplace. In our definitions we consider a household an "entrepreneur household" if the household's main income depends on someone who is in charge of their own business and has employees. Those who run their own businesses but do not have employees are in an intermediate category between entrepreneurs and employees; they may be either opportunity or necessity entrepreneurs. In our estimations we do not consider them entrepreneurs; instead, we refer to them as self-employed.

\subsection{Descriptive Statistics}

Figure 1 presents an overview of income evolution during the period of study. The picture shows the general growth trend and the years of the two large crisis episodes during the 
last 30 years in Uruguay: 1982 and 2002. Figure 2 presents the evolution of income per groups of interest. All groups follow the same trend and are similarly affected by the business cycle. There are sizeable income differences. Entrepreneurs' households have on average about three times the per capita income of the self-employed who do not have a fixed workplace; they have 80 percent more income than the self-employed who have a fixed workplace, and the other employed. The self-employed who lack a fixed workplace are stuck in low-productivity occupations, which accounts for the low income expected of necessity entrepreneurs. The per capita income in Montevideo is about 70 percent higher than the rest of the country. Households with more educated heads have about 100 percent higher incomes than households with less-educated heads. There are no sizeable differences in per capita income between male and female household heads. This is not contrary to typical gender income differences. Female household heads are not a random sample of females; they have different characteristics than other females. ${ }^{2}$

Although the evidence indicates that entrepreneurs tend to be wealthier than nonentrepreneurs, this has no implication for social mobility. Entrepreneurs have on average larger incomes, but they also experience more volatility. The standard deviation of entrepreneurs' income is twice that of the other employed. The standard deviation of income for both types of the self-employed is lower than that of income for other employed. During the 2002 crisis, income in households without entrepreneurial activity fell by 10 percent. In households with entrepreneurial activity, the decline in income was 15 percent. Here we find a sharp difference between entrepreneurs and other individuals, including the self-employed, since entrepreneurial activity involves substantially more risks than other activities. We find the lower volatility of income of the self-employed surprising. This evidence suggests that they are not true entrepreneurs.

\footnotetext{
${ }^{2}$ Similarly, Gandelman (2009) shows that, on average, female household heads in Latin America are more likely to own their homes. After controlling for the endogeneity of homeownership and female household heads, the author reports a negative association between females and homeownership for most countries.
} 


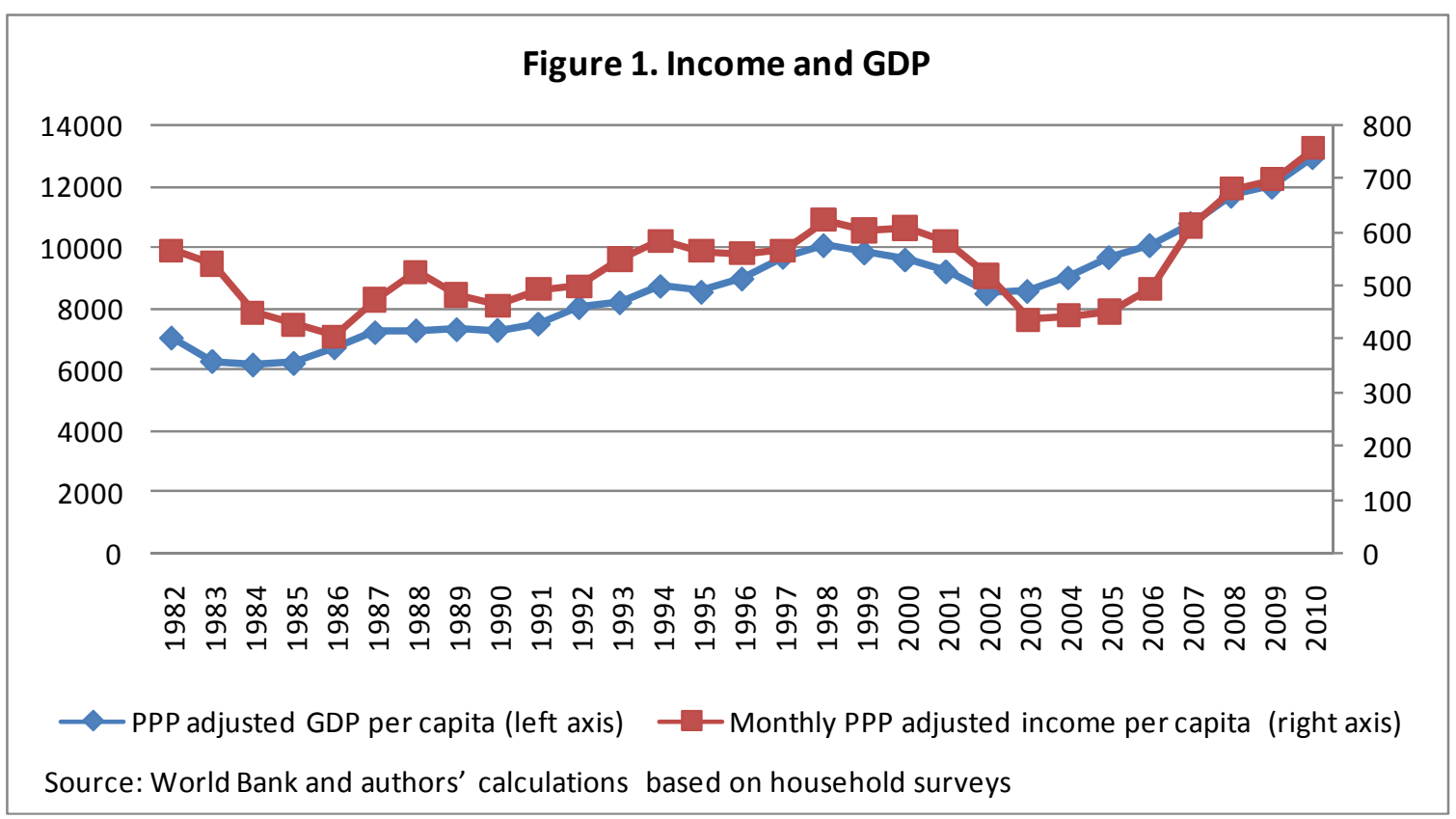




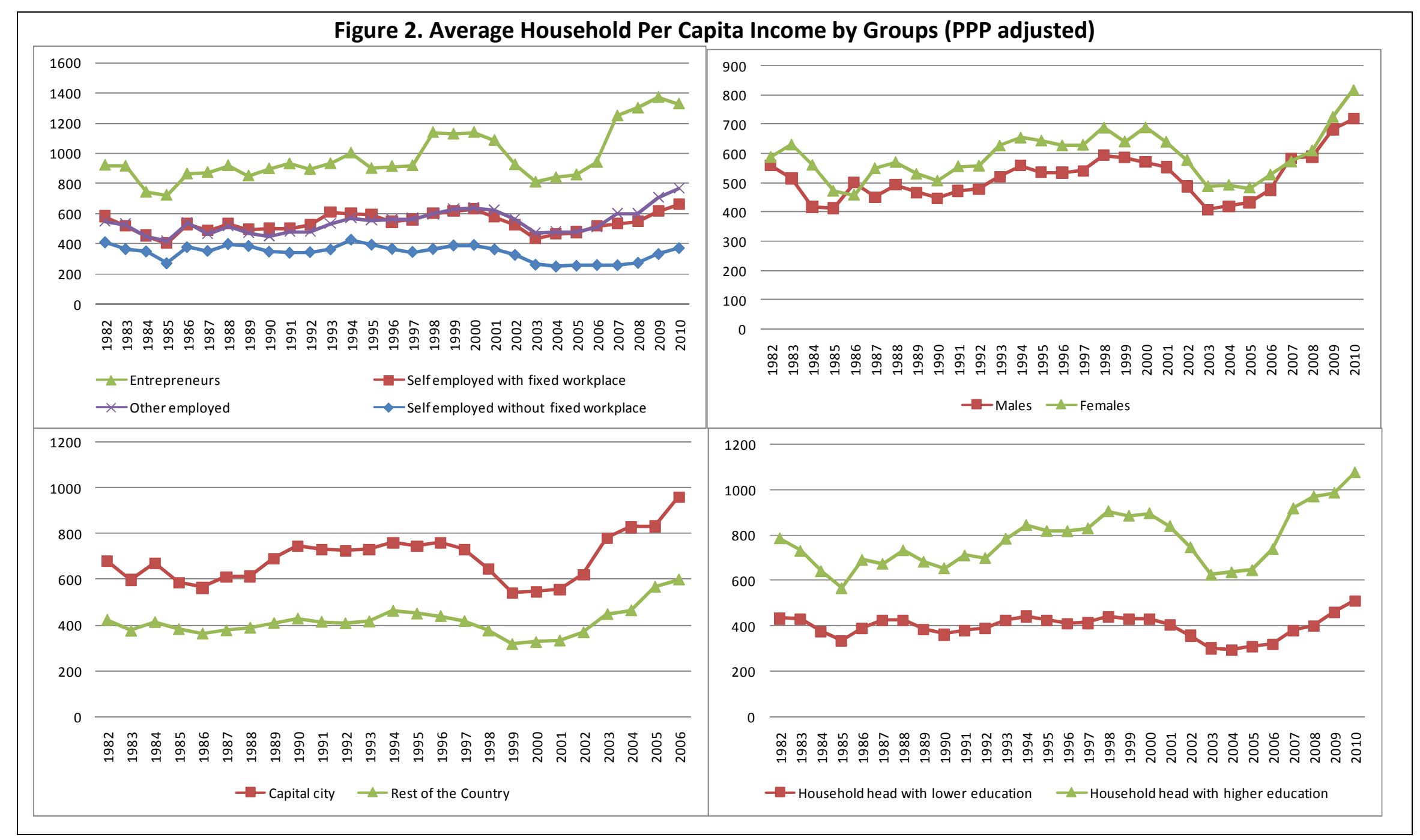

Source: Author`s calculations based on household survey 
Figure 3 reports the percentages of households with entrepreneurship or selfemployment activity. Entrepreneurship and self-employment with fixed workplace are pro-cyclical, which is what we would expect of opportunity entrepreneurs. It is interesting, however, to note that their response to the cycle is of a different magnitude. In the 1999-2002 recessions, entrepreneurs experienced a larger decline than households whose main income came from a self-employed person with a workplace. By contrast, households with self-employment in a workplace show a larger increase than entrepreneurs in the most recent years following the general economic bonanza. It might be that some of these self-employed will end up hiring employees and becoming entrepreneurs according to our definition. As opposed to those two groups, the percentage of self-employed households without a fixed workplace is countercyclical. This suggests that the latter are necessity entrepreneurs who prefer to be employees in a salary-based relationship when the economic situation improves.

On average, there is entrepreneurial activity, i.e., there are business owners with employees, in about 5 percent of households. The self-employed who have a fixed workplace represent 7 percent of households, and the self-employed who do not have a fixed workplace represent 3 percent of households. Kantis et al. (2012) report information on the occupational composition for Argentina, Brazil, Peru, Ecuador, and El Salvador. Our results suggest that Uruguay has about the same level of entrepreneurial activity as Brazil, more activity than Argentina, and less activity than Ecuador and El Salvador. The number of self-employed in Uruguay is well below that of other countries; this is likely due to the lower degree of informality in the Uruguayan labor market. 


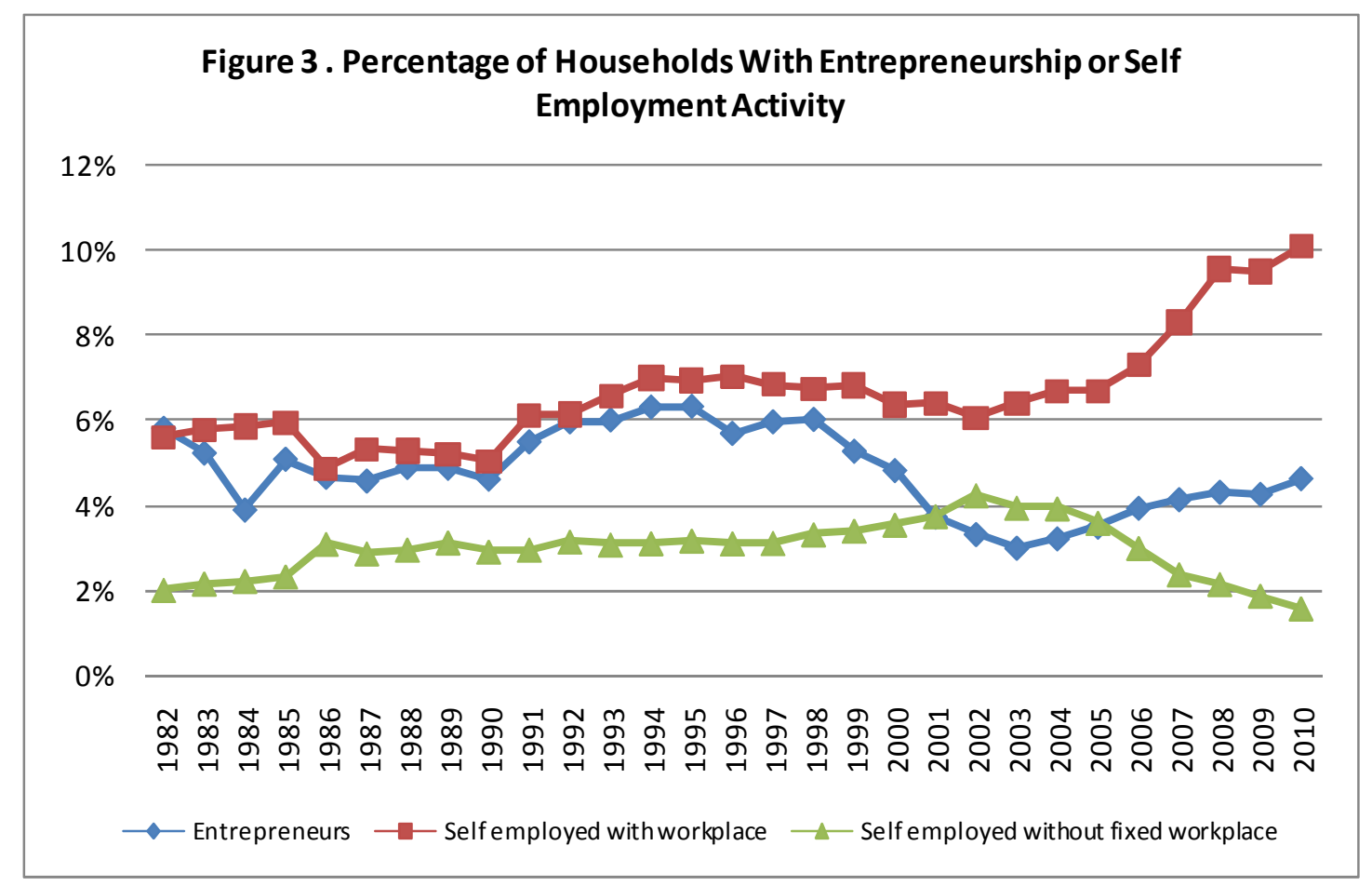

Source: Author`s calculations based on household survey.

Using data from the Global Entrepreneurship Monitor (GEM), in Figure 4 we present total entrepreneurial activity (TEA) as a percentage of GDP for 2007 for selected Latin American countries. Data are classified by social strata, i.e., lower, middle and upper-income. The respondents are classified into necessity entrepreneurs and opportunity entrepreneurs. ${ }^{3}$ Necessity entrepreneurs in Uruguay created less than 5 percent of GDP for 2007 in all three income categories. Opportunity entrepreneurs are overrepresented among the wealthier strata of society.

\footnotetext{
${ }^{3}$ The Global Entrepreneurship Monitor (GEM) defines necessity entrepreneurs as those who are involved in entrepreneurial activity because they have no other option for work. Opportunity entrepreneurs are those who (i) claim to be driven by opportunity, as opposed to finding no other option for work; and (ii) indicate that their main motivation for being involved in opportunity is to be independent or to increase their incomes, as opposed to maintaining their incomes.
} 


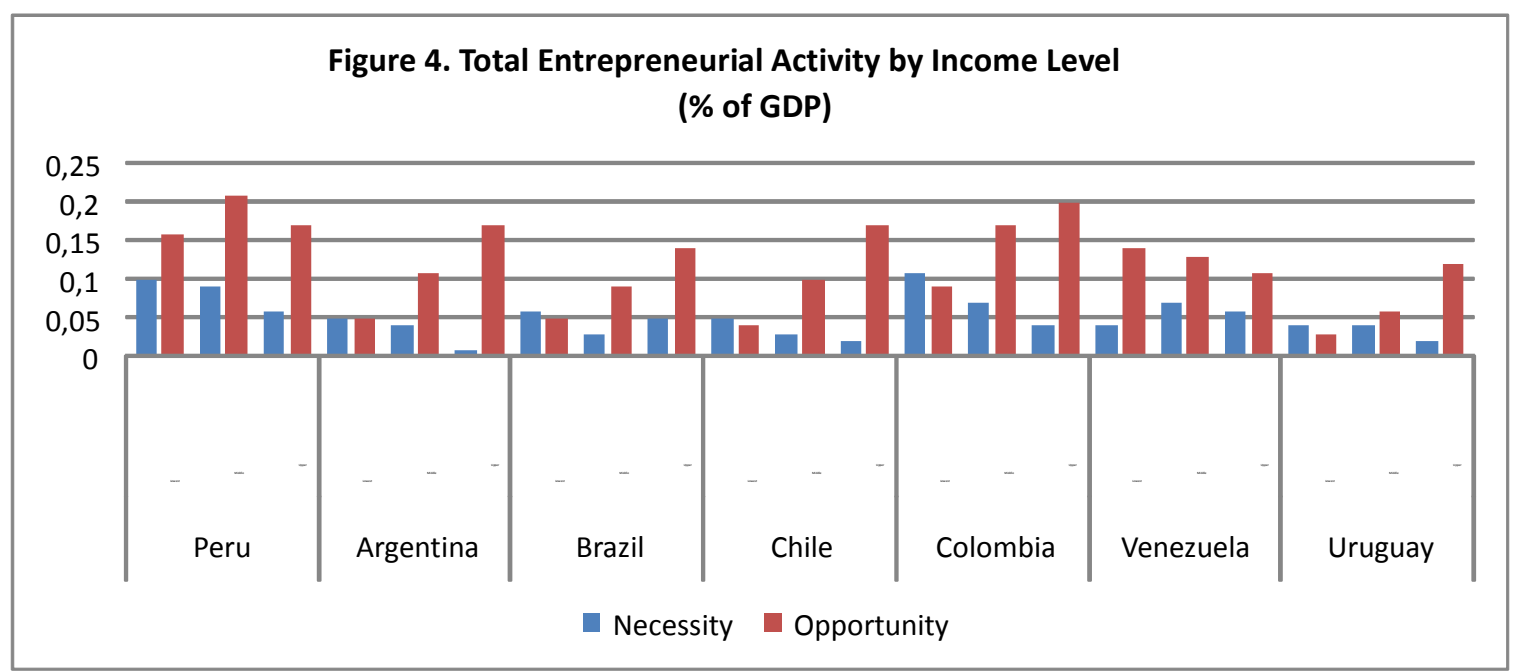

Source: GEM

\section{Results}

Table 3 reports the first set of results. The top panel measures unconditional absolute convergence using PPP adjusted income. The bottom panel measures unconditional relative convergence normalizing income by median values. There are two alternatives to normalizing income. In column A we normalize all cohorts by the median yearly income. In column B we normalize each group by the median yearly income of the group. For example, we normalize all male cohorts by the yearly median income of male household heads and all female cohorts by the yearly median income of female household heads.

The estimates in the top panel are large, but they are statistically different from 1 in most cases. These estimates are similar, or somewhat below, those presented in Table 5, model I of Cuesta et al. (2011) for Uruguay. They show a small level of income convergence.

The lower panel shows the estimates of unconditional convergence for normalized income. The results are less robust than before. The extreme results appear when the cohorts are defined by gender (large convergence) and educational level (almost no convergence). When the cohort is defined by region, education, or entrepreneurship status, the estimations are different according to the normalization used. Convergence 
when normalization is made by peers' yearly income is substantially larger than when the normalization is made by overall yearly income. This suggests that there is more social mobility within cohorts of certain groups than between groups. Recall from Figure 2 that entrepreneurs, people living in the capital city, and those with more education have substantially larger incomes than their counterparts. Our results suggest that although those who do not live in the capital city have a certain level of mobility, their relative standing on the income ladder in relation to those living in the capital city is much more stable than it is in relation to those in their own area. This is similar for entrepreneurs, non-entrepreneurs, and for those who are more or less educated.

Table 4 reports the estimation of equation (3) for subsamples of the population. It shows the degree of mobility within the cohorts of these groups. The top panel shows higher convergence among females than among males and higher convergence in the capital city than in the rest of the country. It also shows greater social mobility among the more educated than among the less educated, and greater social mobility among selfemployed and entrepreneurs than among others.

The lower panel shows a similar picture. Like the absolute convergence estimates, we find less social mobility among male household heads than among female household heads, and greater social mobility among entrepreneurs than among other workers. We cannot reject the null hypothesis that social mobility for residents of Montevideo and for residents in the rest of the country is about the same, or that social mobility for the more educated and less educated is also about the same. 
Table 3. Social Mobility According to Various Alternative Cohort Definitions

\begin{tabular}{|c|c|c|c|c|c|c|c|c|c|c|c|c|c|c|}
\hline \multicolumn{15}{|c|}{ Cohorts defined by: } \\
\hline & & $\begin{array}{l}\text { Birth } \\
\text { date }\end{array}$ & \multicolumn{2}{|c|}{$\begin{array}{c}\text { Birth date } \& \\
\text { entrepreneurship }\end{array}$} & $\begin{array}{l}\text { Birth da } \\
\text { employn } \\
\text { fixed w }\end{array}$ & $\begin{array}{l}\text { te \& self } \\
\text { hent with } \\
\text { orkplace }\end{array}$ & \multicolumn{2}{|c|}{$\begin{array}{l}\text { Birth date \& self } \\
\text { employment } \\
\text { without fixed } \\
\text { workplace }\end{array}$} & \multicolumn{2}{|c|}{ Birth date \& gender } & \multicolumn{2}{|c|}{ Birth date \& region } & \multicolumn{2}{|c|}{$\begin{array}{c}\text { Birth date \& } \\
\text { education level }\end{array}$} \\
\hline \multirow{4}{*}{$\begin{array}{c}\text { Absolute } \\
\text { convergence } \\
\text { (PPP adjusted } \\
\text { income in logs) }\end{array}$} & Lag log income & $0.838 * * *$ & & \multicolumn{2}{|c|}{$0.844 * * *$} & \multicolumn{2}{|c|}{$0.858 * * *$} & \multicolumn{2}{|c|}{$0.744 * * *$} & \multicolumn{2}{|c|}{$0.915^{* * *}$} & \multicolumn{2}{|c|}{$0.940 * * *$} \\
\hline & & $(0.0420)$ & \multicolumn{2}{|c|}{$(0.0203)$} & \multicolumn{2}{|c|}{$(0.0336)$} & \multicolumn{2}{|c|}{$(0.0263)$} & \multicolumn{2}{|c|}{$(0.0341)$} & \multicolumn{2}{|c|}{$(0.0223)$} & \multicolumn{2}{|c|}{$(0.0192)$} \\
\hline & Observations & 224 & \multicolumn{2}{|c|}{448} & \multicolumn{2}{|c|}{448} & \multicolumn{2}{|c|}{448} & \multicolumn{2}{|c|}{448} & \multicolumn{2}{|c|}{448} & \multicolumn{2}{|c|}{448} \\
\hline & Cohorts & 13 & \multicolumn{2}{|c|}{26} & \multicolumn{2}{|c|}{26} & \multicolumn{2}{|c|}{26} & \multicolumn{2}{|c|}{26} & & 6 & & 6 \\
\hline & & & $A$ & B & $A$ & B & A & B & A & B & A & B & $A$ & B \\
\hline Relative & Lag log income & $0.844 * * *$ & $0.938 * * *$ & $0.712 * * *$ & $0.693 * * *$ & $0.718 * * *$ & $0.936 * * *$ & $0.709 * * *$ & $0.699 * * *$ & $0.706 * * *$ & $0.939 * * *$ & $0.847 * * *$ & $0.980 * * *$ & $0.865 * * *$ \\
\hline convergence & & $(0.0336)$ & (0.0159) & $(0.0316)$ & (0.0329) & $(0.0315)$ & $(0.0200)$ & $(0.0334)$ & $(0.0329)$ & $(0.0330)$ & $(0.0167)$ & $(0.0237)$ & (0.0109) & $(0.0235)$ \\
\hline (Income & $\mathrm{R} 2$ & 0.618 & 0.450 & 0.396 & 0.345 & 0.421 & 0.236 & 0.323 & 0.292 & 0.358 & 0.479 & 0.572 & 0.405 & 0.493 \\
\hline median) & Cohorts & 13 & 26 & 26 & 26 & 26 & 26 & 26 & 26 & 26 & 26 & 26 & 26 & 26 \\
\hline
\end{tabular}

Standard errors in parentheses

* significant at $10 \%$; $* *$ significant at $5 \%$; ** significant at $1 \%$

$A=$ income normalized by median annual income.

$B=$ income normalized by median annual income of peers (i.e. entrepreneurs, same region, gender, or educational level) 
Documento de Investigación - ISSN 1688-6275 - No. 78 - 2012 - Bukstein, D., Gandelman, N.

\begin{tabular}{|c|c|c|c|c|c|c|c|c|c|c|c|}
\hline \multicolumn{12}{|c|}{ Table 4. Social Mobility Within Groups } \\
\hline & & Entrepreneurs & $\begin{array}{c}\text { Self } \\
\text { employed } \\
\text { with fixed } \\
\text { workplace }\end{array}$ & $\begin{array}{c}\text { Self } \\
\text { employed } \\
\text { without } \\
\text { fixed } \\
\text { workplace }\end{array}$ & $\begin{array}{c}\text { Other } \\
\text { employed }\end{array}$ & Males & Females & Capital city & $\begin{array}{l}\text { Rest of the } \\
\text { country }\end{array}$ & $\begin{array}{l}\text { Lower } \\
\text { education }\end{array}$ & $\begin{array}{c}\text { Higher } \\
\text { education }\end{array}$ \\
\hline \multirow{4}{*}{$\begin{array}{c}\text { Absolute } \\
\text { convergence } \\
\text { (PPP adjusted } \\
\text { income in logs) }\end{array}$} & Lag log income & $\begin{array}{c}0.702 * * * \\
(0.0501)\end{array}$ & $\begin{array}{c}0.592^{* * *} \\
(0.0549)\end{array}$ & $\begin{array}{c}0.735^{* * *} \\
(0.0444)\end{array}$ & $\begin{array}{c}0.851^{* * *} \\
(0.0423)\end{array}$ & $\begin{array}{c}0.840 * * * \\
(0.0408)\end{array}$ & $\begin{array}{c}0.623 * * * \\
(0.0561)\end{array}$ & $\begin{array}{c}0.784^{* * *} \\
(0.0457)\end{array}$ & $\begin{array}{c}0.909 * * * \\
(0.0413)\end{array}$ & $\begin{array}{c}0.867^{* * *} \\
(0.0368)\end{array}$ & $\begin{array}{c}0.813^{* * *} \\
(0.0438)\end{array}$ \\
\hline & R2 & 0.4448 & 0.316 & 0.222 & 0.620 & 0.6268 & 0.2927 & 0.5551 & 0.6555 & 0.5379 & 0.5821 \\
\hline & Observations & 224 & 224 & 224 & 224 & 224 & 224 & 224 & 224 & 224 & 224 \\
\hline & Cohorts & 13 & 13 & 13 & 13 & 13 & 13 & 13 & 13 & 13 & 13 \\
\hline \multirow{5}{*}{$\begin{array}{l}\text { Relative } \\
\text { convergence } \\
\text { (Income } \\
\text { normalized by } \\
\text { median) /B }\end{array}$} & Lag log income & $0.657^{* * *}$ & $0.564 * * *$ & $0.643 * * *$ & $0.821 * * *$ & $0.848 * * *$ & $0.566^{* * *}$ & $0.853 * * *$ & $0.833^{* * *}$ & $0.869 * * *$ & $0.834 * * *$ \\
\hline & & $(0.0478)$ & $(0.0529)$ & $(0.0525)$ & $(0.0373)$ & $(0.0314)$ & $(0.0560)$ & $(0.0324)$ & $(0.0354)$ & (0.0338) & $(0.0348)$ \\
\hline & $\mathrm{R} 2$ & 0.331 & 0.297 & 0.222 & 0.521 & 0.670 & 0.180 & 0.650 & 0.476 & 0.508 & 0.475 \\
\hline & Observations & 224 & 224 & 224 & 224 & 224 & 224 & 224 & 224 & 224 & 224 \\
\hline & Cohorts & 13 & 13 & 13 & 13 & 13 & 13 & 13 & 13 & 13 & 13 \\
\hline
\end{tabular}

Standard errors in parentheses

* significant at $10 \% ;{ }^{* *}$ significant at $5 \%$; ${ }^{* * *}$ significant at $1 \%$

$\mathrm{B}=$ income normalized by median annual income of peers (i.e. entrepreneurs, same region, gender or educational level) 
Tables 5 and 6 present measures of conditional convergence corresponding to equation (6). Table 5 refers to absolute convergence using PPP adjusted income, while Table 6 refers to relative convergence using normalized income.

Table 5 shows that entrepreneurs have greater social mobility than nonentrepreneurs. Entrepreneurship reduces the coefficient of social mobility by about 0.134. Similarly, we find that both types of the self-employed have greater social mobility than other individuals.

We also find that females and inhabitants of the capital city experience more absolute conditional convergence than males and inhabitants of the rest of the country, respectively. We did not find differences in absolute conditional mobility that can be attributed to the household head's educational level.

Table 6 presents a similar picture. When cohorts are defined by birth year and entrepreneurship, we find greater mobility among entrepreneurs than among nonentrepreneurs. Similarly, we find greater social mobility for the self-employed. Both Tables 5 and 6 suggest that the self-employed with a fixed workplace experience the greatest social mobility, followed by entrepreneurs, the self-employed without a fixed workplace, and other employees. We also find that using this relative measure of income, there is more conditional convergence among females. The result for regions and educational levels is less robust. We find greater mobility in the capital city and among the more educated only when income is normalized according to overall income.

The greater social mobility of entrepreneurs and females implies that their income is more volatile than that of other sectors of society, i.e., they face higher risks. That entrepreneurs face higher risks is expected by definition. Less obvious is the result for female household heads, which implies that they are more vulnerable in general and to economic shocks in particular. 
Documento de Investigación - ISSN 1688-6275 - No. 78 - 2012 - Bukstein, D., Gandelman, N.

\begin{tabular}{|c|c|c|c|c|c|c|c|}
\hline & Entrepreneurship & $\begin{array}{l}\text { Self employed } \\
\text { with fixed } \\
\text { workplace }\end{array}$ & $\begin{array}{c}\text { Self employed } \\
\text { without fixed } \\
\text { workplace }\end{array}$ & Gender & Region & Education & All interactions \\
\hline Lag income & $\begin{array}{c}0.836 * * * \\
(0.0558)\end{array}$ & $\begin{array}{c}0.864 * * * \\
(0.0453)\end{array}$ & $\begin{array}{c}0.839 * * * \\
(0.0522)\end{array}$ & $\begin{array}{c}0.840 * * * \\
(0.0490)\end{array}$ & $\begin{array}{c}0.930 * * * \\
(0.0481)\end{array}$ & $\begin{array}{c}0.860 * * * \\
(0.0399)\end{array}$ & $\begin{array}{c}0.836 * * * \\
(0.0558)\end{array}$ \\
\hline Lag income *Entrepreneurship & $\begin{array}{c}-0.134 * \\
(0.0700)\end{array}$ & & & & & & $\begin{array}{l}-0.134^{*} \\
(0.0700)\end{array}$ \\
\hline Lag income *Self-employed with fixed workplace & & $\begin{array}{c}-0.273 * * * \\
(0.0676)\end{array}$ & & & & & \\
\hline Lag income *Self-employed without fixed workplace & & & $\begin{array}{l}-0.116^{*} \\
(0.0649)\end{array}$ & & & & \\
\hline Lag income ${ }^{*}$ Female & & & & $\begin{array}{c}-0.217^{* * *} \\
(0.0693)\end{array}$ & & & \\
\hline Lag income * Capital City & & & & & $\begin{array}{c}-0.147 * * \\
(0.0632)\end{array}$ & & \\
\hline Lag income * Higher Education & & & & & & $\begin{array}{l}-0.0464 \\
(0.0577)\end{array}$ & \\
\hline Entrepreneurship & $\begin{array}{c}1.015^{* *} \\
(0.448)\end{array}$ & & & & & & $\begin{array}{l}1.015^{* *} \\
(0.448)\end{array}$ \\
\hline Self-employed with fixed workplace & & $\begin{array}{c}1.688 * * * \\
(0.419)\end{array}$ & & & & & \\
\hline Self-employed without fixed workplace & & & $\begin{array}{c}0.569 \\
(0.392)\end{array}$ & & & & \\
\hline Female & & & & $\begin{array}{c}1.373 * * * \\
(0.432)\end{array}$ & & & \\
\hline Capital City & & & & & $\begin{array}{c}0.979 * * \\
(0.387)\end{array}$ & & \\
\hline Higher Education & & & & & & $\begin{array}{c}0.418 \\
(0.359)\end{array}$ & \\
\hline $\mathrm{R} 2$ & 0.500 & 0.498 & 0.408 & 0.4597 & 0.6029 & 0.5626 & 0.500 \\
\hline Observations & 448 & 448 & 448 & 448 & 448 & 448 & 448 \\
\hline Cohorts & 26 & 26 & 26 & 26 & 26 & 26 & 26 \\
\hline
\end{tabular}

Standard errors in parentheses ${ }^{*}$ significant at $10 \% ;{ }^{* *}$ significant at $5 \% ;{ }^{* * *}$ significant at $1 \%$ 


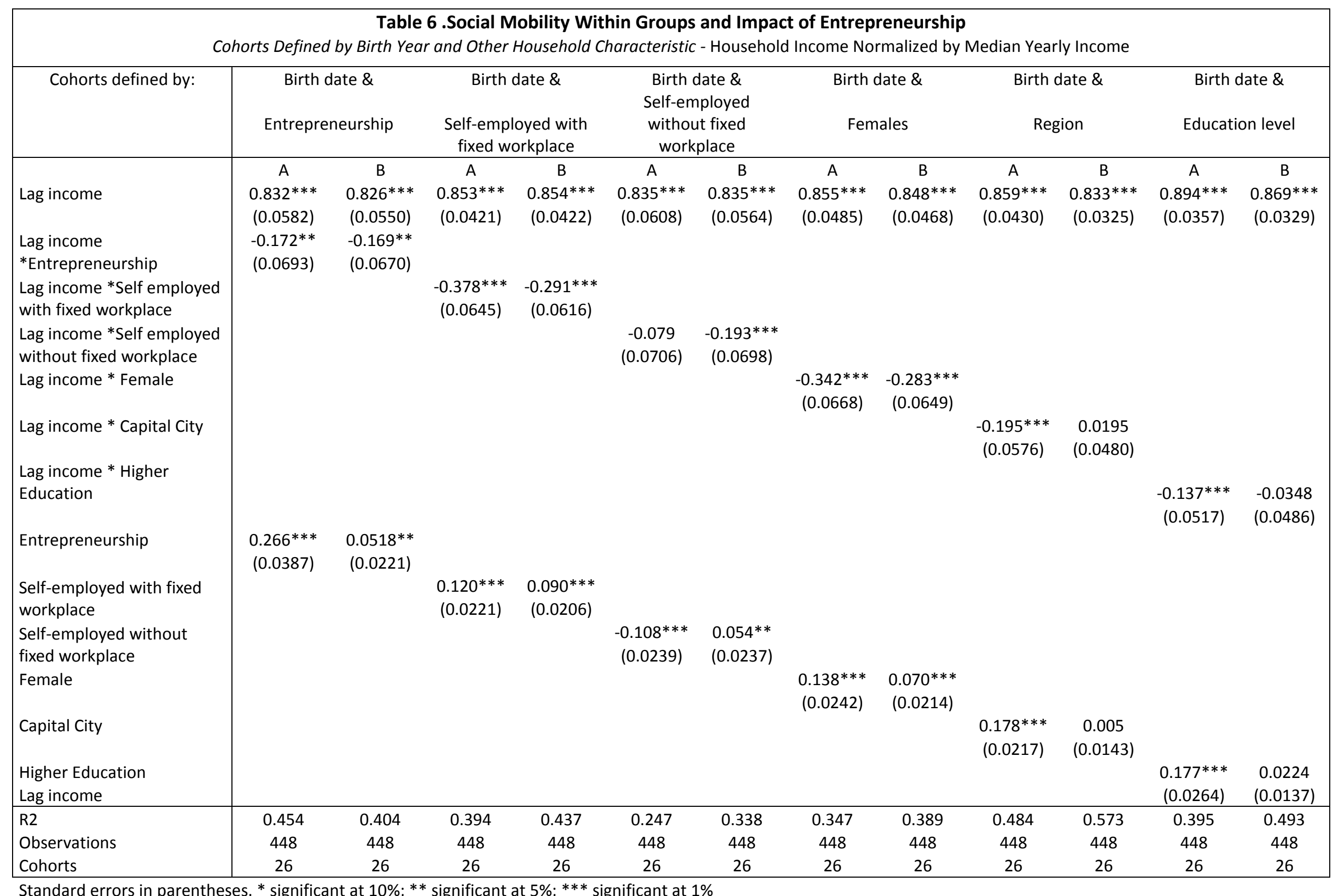




\section{Conclusions}

In this paper we measure intra-generational social mobility in Uruguay using an income time-dependence approach. Using a large pseudo-panel, we find evidence of low unconditional convergence both when using an absolute measure of income and a relative measure of income that controls for income growth. We find evidence suggesting that there is greater mobility within the cohorts of certain groups of the population, i.e., females and residents of the capital city, than between groups.

We address the link between entrepreneurship and social mobility. Entrepreneurship is a difficult concept to measure. We show that business owners with employees have much more income than other employees, but also that they experience much larger income volatility. The self-employed have about the same, or even less, income volatility than other employees. Therefore, there is an important difference in risk-taking between entrepreneurs and the self-employed. We also show that the percentage of households whose main income depends on a business owner with employees evolves pro-cyclically. This also happens for the self-employed with a fixed workplace. The percentage of self-employed without a fixed workplace is countercyclical.

These findings make clear that business owners with employees behave like opportunity entrepreneurs in that they take more risks and follow the business cycle, i.e., in booms there are more business opportunities than in recessions. It is also clear that the self-employed without a fixed workplace are necessity entrepreneurs who would rather have a salaried job. It is less clear what to find about the self-employed with a fixed workplace. Overall, we do not find that they face large risks due to income variability, but they blossom in booms because they follow the business cycle.

Although in this paper the operational definition of entrepreneurs only includes business owners with employees, we also present the results on social mobility for both groups of the self-employed. We find that mobility is much greater for entrepreneurs than non-entrepreneurs. Also we find the self-employed who have a fixed workplace experience even larger income mobility.

The methodology used in this paper does not allow for measuring upward and downward mobility. The greater mobility of entrepreneurs is a confirmation of the larger 
risks that they face. These larger risks are not only a part of their work; these risks affect their families and their household's disposable income. With all other factors constant, entrepreneurs with lower socioeconomic status are more likely to move up the social ladder than non-entrepreneurs, but they are also more likely to fall into extreme poverty.

Policies promoting micro-entrepreneurship, such as microfinance programs, should bear this in mind and carefully evaluate the probability of success for potential entrepreneurs. Promoting entrepreneurship is not a safe method for fighting poverty. But the underperformance of Latin American countries in terms of productivity is related to the existence of many low-producing micro-firms (Pages 2010). Governments should not confuse social assistance programs, e.g., transfers, with programs designed to improve the efficiency of resource allocation in society. Rather than social assistance, policies to foster entrepreneurship should have productivity and efficiency as their goals. 


\section{References}

Acemoglu, D. and F. Zilibotti. 1997. Was Prometheus Unbound by Chance? Risk, Diversification, and Growth. Journal of Political Economy 105(4): 709-751.

Acs, Z. 2006. How is Entrepreneurship Good for Economic Growth?. Innovations Journal. Winter.

Andersen, L. E. 2001. Social Mobility in Latin America: Links with Adolescent Schooling. Latin American Research Network Working Paper \#R-433. Washington, DC, United States: Inter-American Development Bank.

Angrist, J. and S. Pischke. 2008. Mostly Harmless Econometrics. Princeton, United States: Princeton University Press.

Antman, F. and D. J. McKenzie. 2005. Earnings Mobility and Measurement Error: A Pseudo- Panel Approach. Palo Alto, United States: Stanford University. Mimeo.

Banerjee, A. and E. Duflo. 2007. What is Middle Class about the Middle Classes around the World? CEPR Discussion Papers 6613. CEPR.

Conconi, A. G. Cruces, S. Olivieri, and R. Sánchez. 2007. E pur si muove? Movilidad, Pobreza y Desigualdad en América Latina. Working Paper 62. CEDLAS.

Cuesta, J., H. Ñopo, and G. Pizzolitto. 2011. Using Pseudo-panels to Estimate Income Mobility in Latin America. IZA Discussion Papers 5449. Institute for the Study of Labor (IZA).

Deaton, A. 1985. Panel Data from Time Series of Cross Sections. Journal of Econometrics 30: 109-126.

---. 1997. The Analysis of Household Surveys: A Microeconometric Approach to Development Policy. Baltimore, United States: Johns Hopkins University Press.

Fields, G. S. 2003. Accounting for Income Inequality and its Change: A New Method, with Application to the Distribution of Earnings in the United States. Research in Labor Economics 22: 1-38.

Gandelman, N. 2009. Female Headed Households and Homeownership in Latin America. Housing Studies 24(4): 525-549.

Moffitt, R. 1993. Identification and Estimation of Dynamic Models with a Time Series of 
Repeated cross-sections. Journal of Econometrics 59: 99-123.

OECD. 2011. Latin American Economic Outlook. Paris, France: OECD Development Centre.

Pagés, C. 2010. The Age of Productivity. Transforming Economies from the Bottom Up. Washington, DC, United States: Inter-American Development Bank, Palgrave MacMillan.

Verbeek, M. and T. Nijman. 1992. Can Cohort Data Be Treated as Genuine Panel Data? Empirical Economics 17(1): 9-23.

Verbeek, M. and F. Vella. 2002. Estimating Dynamic Models from Repeated Crosssections. Leuven, the Netherlands: K.U. Leuven Center for Economic Studies. Mimeo. 